Article

\title{
Anatomical, Physical, Chemical, and Biological Durability Properties of Two Rattan Species of Different Diameter Classes
}

\author{
Sheikh Ali Ahmed ${ }^{1}\left(\mathbb{D}\right.$, Reza Hosseinpourpia $^{1}\left(\mathbb{D}\right.$, Christian Brischke $^{2}\left(\mathbb{D}\right.$ and Stergios Adamopoulos ${ }^{3, *(\mathbb{D})}$ \\ 1 Department of Forestry and Wood Technology, Faculty of Technology, Linnaeus University, \\ Georg Lückligs Plats 1, 35195 Växjö, Sweden; sheikh.ahmed@lnu.se (S.A.A.); \\ reza.hosseinpourpia@lnu.se (R.H.) \\ 2 Wood Biology and Wood Products, University of Goettingen, Buesgenweg 4, 37077 Goettingen, Germany; \\ christian.brischke@uni-goettingen.de \\ 3 Department of Forest Biomaterials and Technology, Division of Wood Science and Technology, Swedish \\ University of Agricultural Sciences, Vallvägen 9C, 75007 Uppsala, Sweden \\ * Correspondence: stergios.adamopoulos@slu.se; Tel.: +46-018-67-2474
}

check for updates

Citation: Ahmed, S.A.;

Hosseinpourpia, R.; Brischke, C.; Adamopoulos, S. Anatomical, Physical, Chemical, and Biological Durability Properties of Two Rattan Species of Different Diameter Classes. Forests 2022, 13, 132. https:// doi.org/10.3390/f13010132

Academic Editors: Vicelina Sousa, Helena Pereira and Teresa Quilhó

Received: 16 November 2021

Accepted: 14 January 2022

Published: 17 January 2022

Publisher's Note: MDPI stays neutral with regard to jurisdictional claims in published maps and institutional affiliations.

Copyright: (C) 2022 by the authors. Licensee MDPI, Basel, Switzerland. This article is an open access article distributed under the terms and conditions of the Creative Commons Attribution (CC BY) license (https:// creativecommons.org/licenses/by/ $4.0 /)$.

\begin{abstract}
Rattan cane is an important forest product with economic value. Its anatomical, physical, and biological properties vary with the cane height. This makes it difficult to select the appropriate cane diameter for harvesting. Understanding the material properties of rattan cane with different diameter sizes is important to enhance its utilization and performance for different end uses. Thus, the present study was performed on two rattan species, Calamus zollingeri and Calamus ornatus, at two different cane heights (bottom/mature and top/juvenile). Calamus zollingeri was studied at diameter classes of $20 \mathrm{~mm}$ and $30 \mathrm{~mm}$, while Calamus ornatus was analyzed at diameter class of $15 \mathrm{~mm}$. The anatomical properties, basic density, volumetric swelling, dynamic moisture sorption, and biological durability of rattan samples were studied. The results showed that $C$. zollingeri with a $20 \mathrm{~mm}$ diameter exhibited the highest basic density, hydrophobicity, dimensional stability, and durability against mold and white-rot (Trametes versicolor) fungi. As confirmed by anatomical studies, this could be due to the higher vascular bundle frequency and longer thick-walled fibers that led to a denser structure than in the other categories. In addition, the lignin content might have a positive effect on the mass loss of different rattan canes caused by white-rot decay.
\end{abstract}

Keywords: Calamus zollingeri; Calamus ornatus; dynamic vapor sorption; basic density; volumetric swelling; white rot; mold

\section{Introduction}

Rattan are spiny and climbing palms mainly distributed in Southeast Asia and in West and Central Africa [1]. With diverse uses, rattan have a high economic value and the most popular use is in furniture production. Depending on the stem diameter, rattan canes are generally classified into three categories: i.e., large ( $>18 \mathrm{~mm})$, medium $(10-18 \mathrm{~mm})$, and small $(<10 \mathrm{~mm})$ diameter rattan. The medium and large diameter canes are used for furniture frames, walking sticks, sporting goods, and rural bridges, while small diameter canes are used either in round or split form, in basket making, chair seats, lampshades, and a variety of handicraft items [2]. Rattan canes are also widely used as excellent natural materials for ropes, decorative items, housing, craft products, umbrella handles, sporting goods, hats, cordage, birdcages, matting, baskets, hoops, and as implant materials [3,4]. In addition, other parts of the rattan, such as roots, fruits, and leaves, are used in folk medicines, while the shoots are edible because of the presence of high amounts of proteins, carbohydrates, vitamins, and other nutrients [5]. There are 12 different genera of rattan, which include more than 550 species [6], and only four of the genera are traded commercially, i.e., Calamus, Daemonorops, Korthalsia, and Plectocomia [7]. Among them, Calamus is the most species-rich genus of all palms with an estimated 374 species. Calamus grows over a large area and has 
excellent properties and extensive commercial uses. However, studies on this genus are still quite scarce. Commercially harvested rattan undergoes physico-chemical treatment and mechanical processing. Physico-chemical treatment involves seasoning or curing, which is boiling in oil, followed by drying, fumigation, bleaching, and deglazing. Deglazing or polishing is the mechanical removal of the highly silicified epidermis, enabling an easy bending of the cane to desired shapes [1]. Furthermore, scraping and polishing are used to smoothen the surfaces. Semi- or full polishing is done at various stages of the workflow and can be done after cutting, bending, molding, or assembling, and during the finishing process [8].

Rattan are monocotyledonous plants, and their stems are composed of vascular bundles embedded in the parenchymatous tissue. Rattan lacks the necessary lateral meristems to undergo secondary growth and thus only limited diameter growth is possible through ground parenchyma cell enlargement. Properties of the vascular bundle, such as the cell wall thickness of fibers, fiber ratio, and diameter of vessel elements in metaxylem, affect the moisture properties and volumetric shrinkage of rattan [9]. Vascular bundles in rattan canes provide the main reinforcing elements, together with their surrounding fiber sheaths. Remarkably, these reinforcing elements are densely distributed in the outer region and sparsely in the inner region [10]. Like other lignocellulosic materials, the physicomechanical properties of rattan are the most important factors for determination of cane processing and utilization. Those properties are influenced by the species, stem position, diameter, internode length, and density [5]. Different properties of rattan have previously been investigated, including moisture content (MC), density, bending modulus of elasticity, modulus of rupture, axial compression strength, and tensile strength [11]. Also, the factors influencing mechanical properties, such as species [12], microfibril angle [13], anatomical characteristics, temperature, MC, and test methods [14,15], have been discussed. However, it is hardly possible to make a comprehensive conclusion since the properties of rattan canes vary considerably with plant height $[11,16]$. Trees undergo secondary growth and age-related variability in wood properties is evident, but such variability is not apparent in rattan canes because of the absence of secondary growth [17].

Rattan canes have long been used in different applications; however, they exhibit the typical drawbacks of lignocellulosic materials, i.e., dimensional instability, low resistance against mold and rot fungi decay, and strength loss with increasing moisture content $[18,19]$. It is therefore required to complete our knowledge of those fundamental properties as they vary with cane diameter and vertical position. Thus, the aim of this study is to analyze the anatomical variations, basic density, volumetric swelling, chemical composition, vapor sorption, and resistance against mold and fungal decay of two rattan species, Calamus zollingeri and Calamus ornatus, in two different heights (bottom/mature and top/juvenile), and three diameter classes. The results of this study will provide the scientific basis for a wiser utilization of rattan canes, such as allocating the right parts and dimensions for specific final products.

\section{Materials and Methods}

\subsection{Source of Material}

Rattan canes of Calamus zollingeri Beccari and Calamus ornatus Blume grown in Sulawesi, Indonesia were collected from local suppliers for this study. Those canes were commercially polished using a custom-made sanding machine upon which sandpaper was used with a grit size of 220. The canes were $3000 \mathrm{~mm}$ long and belonged to three diameter classes, viz. 30, 20, and $15 \mathrm{~mm}$. Both semi- and fully polished samples were used for C. zollingeri while only fully polished samples were used for C. ornatus. Samples of about $400 \mathrm{~mm}$ long were cut from the bottom and top ends of rattan canes to separate the mature and juvenile portions, respectively. Working samples for physical and anatomical studies were converted from these $400 \mathrm{~mm}$ internode samples (Figure 1). Only fully polished samples were used for testing anatomical characteristics and vapor sorption as no 
differences were expected between semi- and fully polished samples, except from removal of the epidermis and some part of the cortex tissues, as seen in Figure 1.
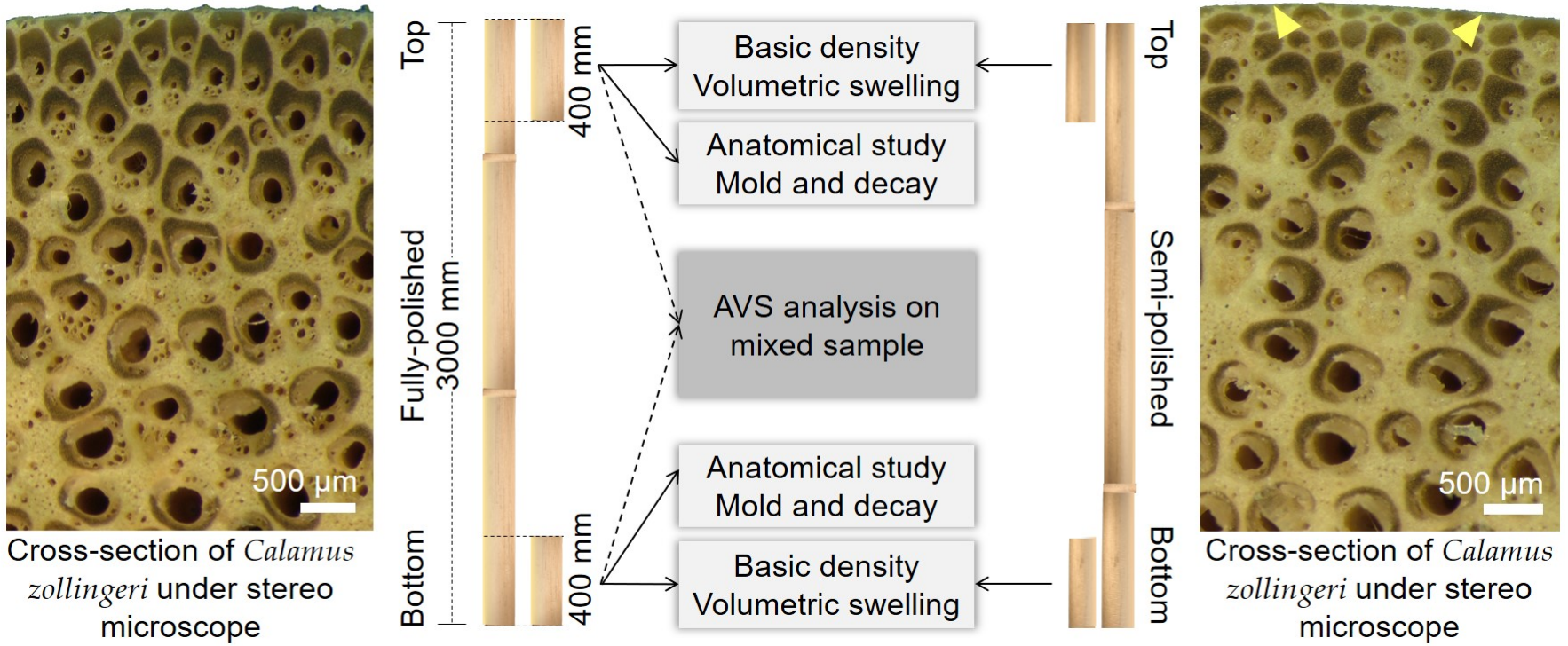

Figure 1. Schematic diagram of sample preparation and analyses. AVS: automated vapor sorption. Arrowheads in semi-polished sample show some cortex tissues. Cane length and diameter are not true to scale.

The number of samples used in this experiment per rattan species and diameter classes are shown in Table 1.

Table 1. Number of samples used per rattan species and diameter classes. Values in parentheses are standard deviations.

\begin{tabular}{lcccccc}
\hline \multirow{2}{*}{ Sample } & \multirow{2}{*}{ Diameter Class } & \multirow{2}{*}{ Mean Diameter mm } & \multicolumn{2}{c}{ Semi-Polished } & \multicolumn{2}{c}{ Fully-Polished } \\
\cline { 4 - 7 } & & & Bottom & Top & Bottom & Top \\
\hline C. zollingeri & 30 & $30.33( \pm 1.41)$ & 8 & 8 & 8 & 8 \\
\hline C. zollingeri & 20 & $18.62( \pm 1.29)$ & 8 & 8 & 8 & 8 \\
\hline C. ornatus & 15 & $14.76( \pm 0.29)$ & - & - & 8 & 8 \\
\hline
\end{tabular}

\subsection{Frequency of Vascular Bundles and Fiber Length}

For analyzing the frequency of vascular bundles, $20 \mathrm{~mm}$ thick discs were cut from the cane and then blocks about $10 \mathrm{~mm}$ wide along the diameter were prepared. Sample blocks were then soaked in water for $8 \mathrm{~h}$ for softening. Cross-sections of 15-20 $\mu \mathrm{m}$ thick strips from periphery to periphery were prepared from the bottom and top samples of C. zollingeri and C. ornatus using a sledge microtome (WSL, Birmensdorf, Switzerland). One (1) sample per rattan species and portion (bottom and top) was used, i.e., a total of six randomly selected samples. The sections were stained with 1:1 solution of $1 \%$ Safranin O (Merck KGaA, Darmstadt, Germany) and Astra blue (Carl Roth GmbH, Karlsruhe, Germany) solution, washed with a series of alcohol solutions, and finally fixed on glass slides with Entellan $^{\mathrm{TM}}$ mounting agent (Merck KGaA, Darmstadt, Germany). The glass slides were observed under a motorized Olympus BX63F light microscope (Tokyo, Japan) equipped with a DP73 color CCD cooled camera (max. 17.28 megapixel) and software program OLYMPUS cellSens Dimension, version 1.18 (Olympus, Tokyo, Japan). For every sample, the numbers of vascular bundles $/ \mathrm{mm}^{2}$ area were counted from periphery to periphery. The vascular bundle consists of the conducting tissue, phloem, and xylem with fibers that provide structural support. Vascular bundles were counted in one $\mathrm{mm}^{2}$ rectangle area. 
Those vascular bundles were also counted as one when at least $50 \%$ of the area fell in one $\mathrm{mm}^{2}$ rectangle.

For analyzing the rattan fiber length, matchstick-sized samples were cut with a razor blade and put in glass vials containing 50:50 solutions by volume of hydrogen peroxide $20 \%$ and glacial acetic acid. The vials were placed in an oven at $60^{\circ} \mathrm{C}$ for 2 days to macerate the material. After that period, the macerations were washed with de-ionized water and were stored in small glass containers with ethanol absolute. One droplet of the suspension containing rattan cells was placed on a slide and was observed under the microscope. Fifty intact fibers per sample (duplicate) were randomly selected to measure the length.

\subsection{Density and Volumetric Swelling}

Basic density values were measured for 80 rattan samples ( $400 \mathrm{~mm}$ long with dimeters of 15,20 , and $30 \mathrm{~mm}$ ). Samples corresponded to the bottom (mature) and top (juvenile) parts of the canes.

Discs about $20 \mathrm{~mm}$ thick were cut from the middle of the original samples to obtain representative values of these cane portions (bottom and top). Samples were weighed on a balance with $0.001 \mathrm{~g}$ accuracy, put in an oven at $103 \pm 2{ }^{\circ} \mathrm{C}$ until constant masses were attained and then the oven-dry masses were recorded. After that, all samples were submerged in a water bath for 14 days for complete saturation of the cell walls [20]. The samples' green volumes were recorded by the water-displacement method. Basic density $(R)$ and volumetric swelling $(S)$ determinations were performed using the following equations:

$$
\begin{gathered}
R\left(\mathrm{~g} / \mathrm{cm}^{3}\right)=\frac{M_{o}}{V_{2}} \\
S(\%)=\frac{V_{2}-V_{1}}{V_{1}} \times 100
\end{gathered}
$$

where $M_{o}$ is the oven-dry mass of each sample in $\mathrm{g}, V_{2}$ is the fully saturated (maximum), and $V_{1}$ is the oven-dried volume in $\mathrm{cm}^{3}$.

\subsection{Chemical Composition Analysis}

Fully polished samples of 30 (length) $\times 10$ (width) $\times 5$ (thickness) $\mathrm{mm}^{3}$ each from the bottom and top of rattan canes were used. The chemical composition of the rattan samples was analyzed according to Ghavidel et al. 2021 [21] by grinding them in a Willey mill through a No. 40 mesh sieve $(0.425 \mathrm{~mm})$. Ground powder from the bottom and top samples were mixed homogenously and then analyzed for chemical compositions. The extractive content was determined on 2-3 g of oven-dried samples (at $103{ }^{\circ} \mathrm{C}$ for $24 \mathrm{~h}$ ) using cyclohexane-ethanol $(50: 50 \mathrm{v} / \mathrm{v})$ solution for $4 \mathrm{~h}$. Then, the samples were oven-dried again and used for the assessment of holocellulose content by transferring to an Erlenmeyer flask, adding $80 \mathrm{~mL}$ of hot water $\left(70^{\circ} \mathrm{C}\right), 1 \mathrm{~g}$ of sodium chlorite, and $0.5 \mathrm{~mL}$ of acetic acid, keeping it for $6 \mathrm{~h}$ in a water bath at $70^{\circ} \mathrm{C}$. Ash content was determined according to the standard EN 15403 [22]. The lignin amount was assessed by subtracting the sum of all other components, i.e., holocellulose, ash, and extractive contents, from $100 \mathrm{wt} \%$. Samples were measured in duplicate to calculate average values.

\subsection{Vapor Sorption Analysis}

The water vapor sorption behaviors of the bottom and top rattan samples were determined using an automated vapor sorption (AVS) apparatus (Q5000 SA, TA Instruments, New Castle, USA) following the procedure described in Hosseinpourpia et al. [23]. Approximately $8 \mathrm{mg}$ of rattan powder (as made for chemical composition analysis) were used for each measurement. The samples were exposed to relative humidity $(\mathrm{RH})$ that was increased from $0 \%$ to $90 \%$ in stepped sequences of $15 \%$ and of $5 \%$ from $90 \%$ to $95 \% \mathrm{RH}$, decreasing to $0 \% \mathrm{RH}$ in a reverse order, at a constant temperature of $25^{\circ} \mathrm{C}$. The instrument maintained a constant target $\mathrm{RH}$ until the mass change in the sample $(\mathrm{dm} / \mathrm{dt})$ was less than $0.01 \%$ per min over a $10 \mathrm{~min}$ period. The equilibrium moisture content $(\mathrm{EMC})$ of the 
rattan samples was calculated based on their equilibrium weight at each given RH step throughout the sorption run measured by a micro balance.

\subsection{Durability Tests}

\subsubsection{Mold}

Fully polished samples of 30 (length) $\times 10$ (width) $\times 5$ (thickness) $\mathrm{mm}^{3}$ were used for both mold and decay tests. All samples were conditioned at $20^{\circ} \mathrm{C}$ and $65 \% \mathrm{RH}$ in a climate chamber for three weeks before testing. An accelerated laboratory mold test was performed in a Memmert HCP 246 humidity chamber (Memmert GmbH, Germany), according to a previous study [24]. Five replications from each group giving a total of 30 samples were used for the accelerated mold test. Samples were suspended from the top of the chamber's support bars with the flat surface set vertical and parallel to the other sample surfaces with a $10 \mathrm{~mm}$ gap between in a randomly ordered fashion. The temperature and $\mathrm{RH}$ were then set to be $27^{\circ} \mathrm{C}$ and $95 \%$, respectively. Three Scots pine sapwood (Pinus sylvestris L.) samples infested mainly with Aspergillus, Rhizopus, and Penicillium genera were placed on the bottom of the climate chamber to be the sources of mold inocula. After 10 days of incubation, the experiment was stopped because of abundant mold growth on some of the sample surfaces. Both flat surfaces of the samples were evaluated visually and graded on a scale of 0 (no infestation) to 6 (extremely heavy infestation). More about the grading and method can be found in Sehlstedt-Persson et al. [25].

\subsubsection{Basidiomycete Decay Test}

The resistance of the two rattan species against white-rot fungi decay was evaluated with a malt agar incubation test according to EN 113-2 [26]. Deviating from the standard, mini-block specimens of 30 (length) $\times 10$ (width) $\times 5$ (thickness) $\mathrm{mm}^{3}$ [27] were used and incubated for 8 weeks. Fifteen to 25 replicates per group were oven-dried at $103 \pm 2{ }^{\circ} \mathrm{C}$ till constant mass and weighed to the nearest $0.001 \mathrm{~g}$ to determine the oven-dry mass.

After steam sterilization in an autoclave at $120^{\circ} \mathrm{C}$ for $30 \mathrm{~min}$, sets of two specimens of the same group were placed on fungal mycelium in Kolle flasks (100 ml malt extract agar, 4\%). The white-rot fungus Trametes versicolor (L.) Lloyd. F strain was used for the tests. Furthermore, 10 replicates made from Scots pine sapwood and beech (Fagus sylvatica L.) were used as virulence controls. All specimens were incubated for 8 weeks at $22{ }^{\circ} \mathrm{C}$ and $70 \% \mathrm{RH}$.

After incubation, specimens were cleansed of adhering fungal mycelium, weighed to the nearest to $0.001 \mathrm{~g}$, oven-dried at $103 \pm 2{ }^{\circ} \mathrm{C}$, and weighed again to the nearest $0.001 \mathrm{~g}$ to determine mass loss through wood-destroying basidiomycetes as follows:

$$
M L_{F}=\frac{M_{0}-M_{0, i n c}}{M_{0}} \times 100
$$

where $M L_{F}$ is the mass loss by fungal decay (\%), $M_{0, i n c}$ is the oven-dry mass after incubation $(\mathrm{g})$, and $M_{0}$ is the oven-dry mass before incubation $(\mathrm{g})$.

\subsection{Statistical Analysis}

To determine any statistically significant differences between the bottom and top samples, mean values were compared by a two-tailed group t-test at a 0.05 significance level (Excel 2016 program, Microsoft, Redmond, WA, USA). F-tests for mean fiber length, number of vascular bundles, basic density, volumetric swelling, and mold grades were performed using the IBM SPSS Statistics statistical software package, Version 24 (IBM Corporation, New York, USA). One-way analysis of variance (ANOVA) at a 0.05 significance level was applied to determine significant differences among rattan samples. When significant differences were found, Duncan's multiple-range test was performed. 


\section{Results and Discussion}

\subsection{Anatomical and Physical Properties}

The anatomical characteristics of rattan samples were studied using light microscopy (Figure 2). The vascular bundles in rattan are scattered and embedded in the ground parenchymatous tissues. They are present just below the single layered epidermis and are small and incomplete, consisting of either clusters of fibers or a few phloem and vessel elements with fibers [28]. Vascular bundles present in the center are well developed. In both rattan species, vascular bundles consisted of two phloem fields and one metaxylem vessel and had horseshoe-shaped fibrous tissues. The ground tissue is parenchyma cells. According to Weiner and Liese [28], three forms of parenchyma cells are distinguished in cross sections, i.e., Type A: weakly branched with regular rounded intercellular spaces, Type B: small and rounded cells with irregular shaped intercellular spaces, and Type C: thinwalled, large, and round. The species showed the Type A parenchyma cell arrangement. During processing (polishing), the epidermis and some parts of the cortex were removed (Figure 1).

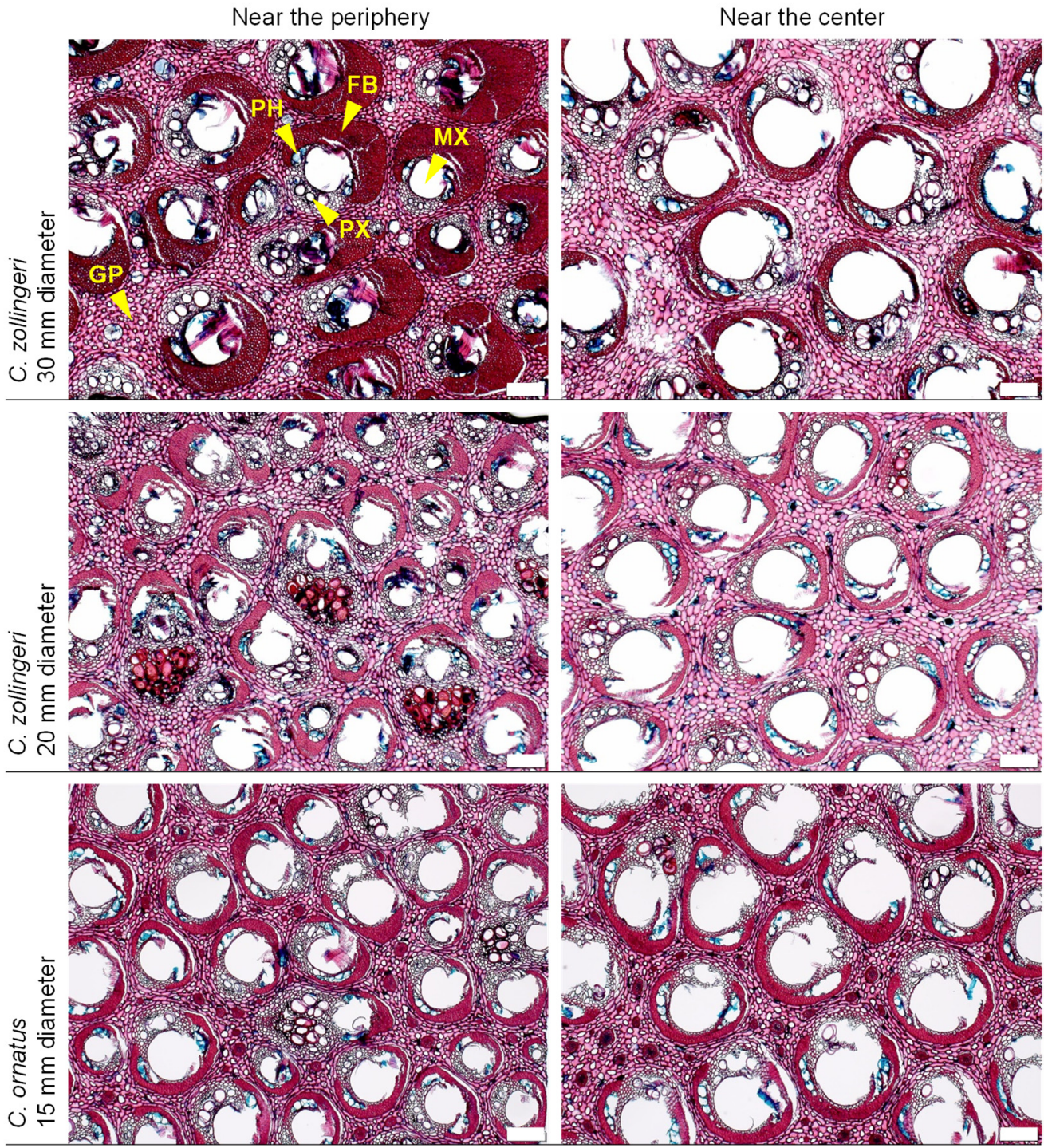

Figure 2. Light microscopic images of cross-sections of $C$. zollingeri and C. ornatus with different diameter classes. Arrow heads show $\mathrm{MX}=$ metaxylem, $\mathrm{PX}=$ protoxylem, $\mathrm{PH}=$ phloem, $\mathrm{FB}=$ fiber bundle, and GP = ground parenchyma. Scale bars $=200 \mu \mathrm{m}$. 
The mean values of fiber length ranged from $1008 \mu \mathrm{m}$ to $1329 \mu \mathrm{m}$, which were in accordance with a previous study [18]. Fiber length and number of vascular bundles of the rattan samples clearly decreased from the bottom to the top (Table 2). A similar trend was also reported in previous findings $[5,16,18,29]$. When all values were considered from the bottom and top of the canes, mean fiber length and number of vascular bundles were found to be significantly higher in C. zollingeri than in C. ornatus. Except for the C. zollingeri that had a $30 \mathrm{~mm}$ diameter, fiber length and number of vascular bundles were significantly higher in the bottom than in the top samples. The number of vascular bundles increased significantly with a decrease in stem diameter (Table 2). Similar results were reported by Bhat et al. [16] with a less consistent longitudinal variation.

Table 2. Mean values of fiber length and number of vascular bundles of different fully polished rattan samples. Mean values ( \pm standard deviations) of $n=100$ per sample type for fiber length.

\begin{tabular}{|c|c|c|c|c|c|c|c|c|c|}
\hline \multirow{2}{*}{ Sample } & \multirow{2}{*}{$\begin{array}{l}\text { Diameter } \\
\text { Class }\end{array}$} & \multicolumn{4}{|c|}{ Fiber Length $(\mu \mathrm{m})$} & \multicolumn{4}{|c|}{ Number of Vascular Bundles $/ \mathrm{mm}^{2}$} \\
\hline & & Bottom & Top & $t$-Value & Mean & Bottom & Top & $t$-Value & Mean \\
\hline C. zollingeri & 30 & $1221( \pm 261) b$ & $1219( \pm 309)$ a & -0.14 & $1220( \pm 285) \mathrm{a}$ & $2.05( \pm 0.32) b$ & $1.72( \pm 0.36) \mathrm{c}$ & -1.22 & $1.89( \pm 0.37) b$ \\
\hline C. zollingeri & 20 & $1329( \pm 390)$ a & $1102( \pm 254) b$ & $-4.96^{*}$ & $1216( \pm 348) \mathrm{a}$ & $3.40( \pm 0.63) \mathrm{a}$ & $3.17( \pm 0.60) \mathrm{a}$ & $-4.38 *$ & $3.30( \pm 0.61) \mathrm{a}$ \\
\hline C. ornatus & 15 & $1209( \pm 297)$ a & $1008( \pm 289) \mathrm{c}$ & $5.00 *$ & $1109( \pm 309) b$ & $3.20( \pm 0.50) \mathrm{a}$ & $2.85( \pm 0.32) b$ & $-2.62 *$ & $3.02( \pm 0.44) \mathrm{a}$ \\
\hline F-value & & $26.31 *$ & $5.06 *$ & & $7.99 *$ & $76.10 *$ & $90.64 *$ & & $148.31 *$ \\
\hline
\end{tabular}

Mean values followed by different letters within a column indicate that there is a significant difference $(p \leq 0.05)$ as determined by ANOVA and Duncan's multiple range test. ${ }^{*}$ Significant differences at the 0.05 level.

The higher frequency of vascular bundles could result in higher basic density. Besides, compression strength and the apparent Young's modulus increases with an increase in the number of vascular bundles [30,31]. It is thus expected that the outer part of rattan cane with densely distributed vascular bundles would have better mechanical strength than the core part with sparse distribution [15]. Anatomical investigations on C. zollingeri and C. ornatus with different diameter classes demonstrate that the fiber length and the number of vascular bundles per unit area varied significantly. Those properties decreased consistently in cane height from bottom to top. As mentioned above, the increase of basic density is dependent on the increase of cell wall thickness. The increase of fiber wall thickness with age is more pronounced than in cortical and ground parenchyma tissues, and the thickening of the fiber wall with increasing stem density results from fibers forming polylamellate walls [32]. Basic density values were positively correlated with the frequency of vascular bundles; however, the correlation was poor $(r=0.39)$. This could be attributed to the differences of share and thickness of fiber cells in rattan samples [16].

The physical properties, i.e., basic density and volumetric swelling, of rattan samples from different diameter classes are shown in Table 3. The top samples of fully polished C. zollingeri with a $20 \mathrm{~mm}$ diameter exhibited the highest basic density. This density was about $32 \%$ higher than in the bottom and top samples of $C$. ornatus with $15 \mathrm{~mm}$ diameters. Those differences were found to be statistically significant. No significant differences were observed in semi- and fully polished C. zollingeri samples between diameter classes (20 and $30 \mathrm{~mm}$ ) and cane height (bottom and top). The density of semi-polished samples was higher than fully polished ones, except for the top samples of $C$. zollingeri with $20 \mathrm{~mm}$ diameters. However, such differences were not evaluated from a statistical point of view. Those density differences could be explained by the fact that semi-polished samples had some remaining cortex. The cortex between epidermis (single cell layer) and the vascular system consists of parenchyma cells, fibers, and incomplete vascular bundles. Higher frequency of vascular bundles, thicker fiber cell walls, and smaller cell sizes in the cortex contribute to higher basic density than in the core $[11,30]$. The basic density tends to decrease with cane height from the basal to the top portion of the cane $[5,29,33]$. This could be attributed to the steady decrease of fiber cells from base to top [15]. However, diverged results of density with cane heights are also reported $[5,11]$. In this study, for both semi- and fully polished samples, no statistical differences of basic density were found between the bottom and top parts. Basic 
density values are the result of various factors, such as the numerous fiber cells with thicker walls, higher vascular bundle frequency, narrower metaxylem vessel elements, and more lignified cells distributed in the cane. In particular, the higher percentage of fibers that constitute the total stem tissue considerably influences the density, and thus proportionally affects the strength properties of rattan cane $[2,15]$.

Table 3. Mean basic density and volumetric swelling values of semi- and fully polished rattan samples in different diameter classes. Mean values ( \pm standard deviations) of $n=8$ per sample type.

\begin{tabular}{|c|c|c|c|c|c|c|c|}
\hline \multirow{3}{*}{ Sample } & \multirow{3}{*}{ Diameter Class } & \multicolumn{3}{|c|}{ Basic Density $\left(\mathrm{g} / \mathrm{cm}^{3}\right)$} & \multicolumn{3}{|c|}{ Volumetric Swelling (\%) } \\
\hline & & \multicolumn{6}{|c|}{ Fully-Polished } \\
\hline & & Bottom & Top & $t$-Value & Bottom & Top & $t$-Value \\
\hline C. zollingeri & 30 & $0.348( \pm 0.051) b$ & $0.335( \pm 0.057) \mathrm{b}$ & -0.76 & $17.39( \pm 2.40) \mathrm{b}$ & $19.06( \pm 6.55) b$ & -0.59 \\
\hline C. zollingeri & 20 & $0.496( \pm 0.036) \mathrm{a}$ & $0.435( \pm 0.076) \mathrm{a}$ & -1.92 & $15.80( \pm 2.30) b$ & $13.79( \pm 1.13) b$ & 1.78 \\
\hline C. ornatus & 15 & $0.289( \pm 0.078) b$ & $0.314( \pm 0.051) b$ & -0.61 & $27.30( \pm 6.13) \mathrm{a}$ & $27.39( \pm 5.64) \mathrm{a}$ & -0.03 \\
\hline \multirow[t]{2}{*}{ F-value } & & $22.77^{*}$ & $7.46^{*}$ & & $14.03 *$ & $6.69 *$ & \\
\hline & & \multicolumn{6}{|c|}{ Semi-polished } \\
\hline C. zollingeri & 30 & $0.438( \pm 0.050)$ & $0.412( \pm 0.052)$ & 0.97 & $15.79( \pm 1.99)$ & $17.82( \pm 3.32)$ & -1.36 \\
\hline C. zollingeri & 20 & $0.458( \pm 0.059)$ & $0.460( \pm 0.069)$ & -0.08 & $15.88( \pm 2.00)$ & $16.22( \pm 1.99)$ & -0.26 \\
\hline $\mathrm{t}$-value & & -0.69 & -1.49 & & -0.08 & 0.89 & \\
\hline
\end{tabular}

Mean values followed by different letters within a column indicate that there is a significant difference $(p \leq 0.05)$ as determined by ANOVA and Duncan's multiple range test. * Significant differences at the 0.05 level.

For fully polished samples, C. ornatus had the highest volumetric swelling, and differences were statistically significant from the other samples (Table 3). In bottom samples with 30 and $20 \mathrm{~mm}$ diameters, C. ornatus demonstrated about $46 \%$ and $42 \%$ higher volumetric swelling than C. zollingeri, respectively. These values were about $31 \%$ and $41 \%$ higher in the top samples of $C$. ornatus than in the top samples of $C$. zollingeri. No significant differences were observed in semi- and fully polished C. zollingeri samples between diameter classes (20 and $30 \mathrm{~mm}$ ) and cane height (bottom and top). These results are in line with previous findings on other species of Calamus [34], although a significant increase of volumetric shrinkage from the bottom to the top of rattan cane is also reported [35]. The higher volumetric swelling values of $C$. ornatus could be caused by its lower basic density. Low basic density implies small cell wall thickness, and this in turn results in higher swelling [36].

Vascular bundles are scattered in the ground tissues (Figure 2). Just below the epidermis, vascular bundles are small and incomplete, consisting of either clusters of fibers or a few phloem and vessel elements with fibers. They are well-developed in the center of the stem cross-section. That implies a within-cane variation of density in the radial direction, i.e., a low-density core with large-diameter and low-frequency vascular bundles that is surrounded by a high-density outer zone with small-diameter and high-frequency vascular bundles [30].

Based on the anatomical and physical properties studied in rattan samples with different diameter classes, C. zollingeri with a $20 \mathrm{~mm}$ diameter showed longer fibers, higher basic density, and the lowest volumetric swelling in both the bottom and top of the canes. Therefore, we anticipate that $C$. zollingeri illustrates a more dimensional-stable character than the other rattan types.

\subsection{Chemical Composition Analysis}

The chemical composition of rattan samples in different diameter classes is shown in Table 4 . The holocellulose content, which was about $78 \%$, was identical in all rattan samples. This value agrees with previous studies [18,37]. The highest lignin content of $17.9 \%$ was obtained in C. zollingeri with a $30 \mathrm{~mm}$ diameter, while the C. ornatus exhibited the lowest lignin content of $9.1 \%$. This might be related to the age of the rattan cane in that 
the cambial cells produce more mature cells with progressing cane age [17]. The content of alcohol-benzene solubles in different rattan species shows a non-specific trend from the bottom to top samples [18,34]. C. ornatus was found to have higher extractive and ash contents compared with other rattan types. $C$. zollingeri with a $20 \mathrm{~mm}$ diameter had higher extractive content than that of $C$. zollingeri with a $30 \mathrm{~mm}$ diameter. The high ash content in material like rattan is generally attributed to the high silica content, which can affect its working properties for some specific applications [34].

Table 4. Chemical composition of rattan samples in different diameter classes (wt\%).

\begin{tabular}{cccccc}
\hline Sample & Diameter Class & Holocellulose & Lignin & Extractives & Ash \\
\hline C. zollingeri & 30 & 78.5 & 17.9 & 1.5 & 2.0 \\
\hline C. zollingeri & 20 & 78.9 & 13.6 & 2.8 & 4.6 \\
\hline C. ornatus & 15 & 78.0 & 9.1 & 5.1 & 7.7 \\
\hline
\end{tabular}

\subsection{Vapor Sorption Analysis}

The MC of rattan is a very important factor as it affects the mechanical properties. Water is a good plasticizer and acts as a softener. Uptake of water loosens the bonds between the structural polymers within the lignocellulosic materials, i.e., lignin, cellulose, and hemicelluloses [38,39]. During vapor sorption analysis, the rattan samples showed the typical sigmoidal character of cellulosic materials (Figure 3). Different moisture sorption behavior was observed in rattan samples at various relative humidities (RHs) during adsorption and desorption processes.
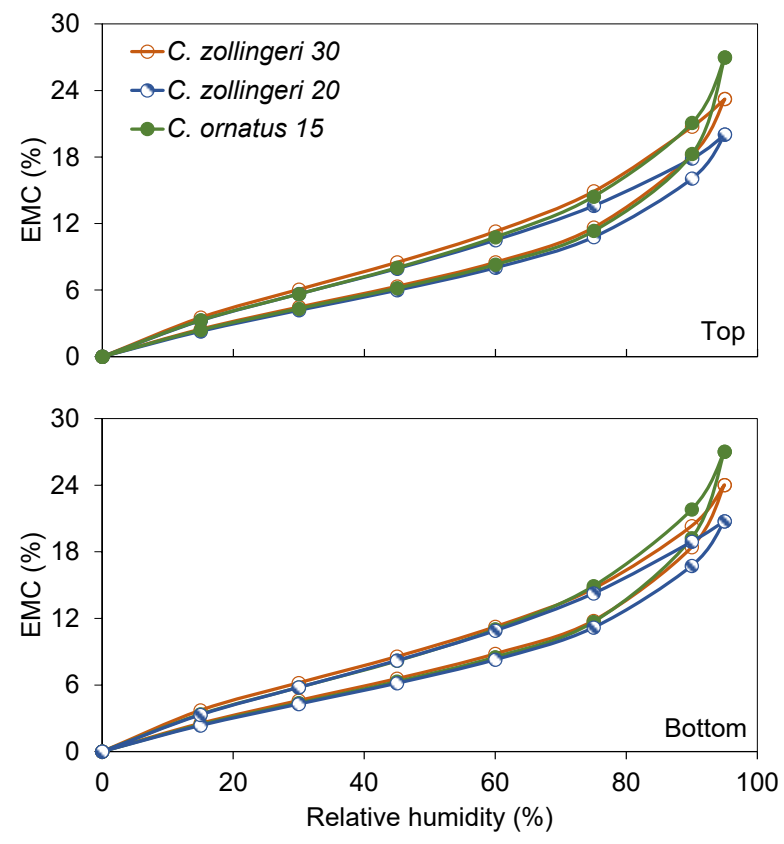

Figure 3. Equilibrium moisture content (EMC) of bottom/mature and top/juvenile rattan samples of different diameter classes $(30,20$, and $15 \mathrm{~mm}$ ) during the adsorption and desorption runs.

The EMC of rattan samples increased with increasing RH from 0 to $95 \%$. Identical EMC values were observed in the top and bottom samples within the same species. There were no differences in the EMC values of the samples at RHs below $60 \%$ during both adsorption and desorption runs. The moisture adsorption isotherms are similar to the one reported by Yang et al. [36]. The highest EMC value was obtained at $95 \% \mathrm{RH}$ for sample $C$. ornatus, which was ca. $27 \%$. The sharp upward bend above $70 \% \mathrm{RH}$ is generally accepted to be related to the softening point of hemicelluloses [40]. Removal of the lignin increased the 
moisture sorption capacity of holocellulose micro-veneers at RH above 75\% [40]. Although the sorption mechanism of the rattan cell wall could be slightly different than wood, it is thus assumed that the higher EMC value of the C. ornatus samples could be mainly related to the lower lignin content as compared to other rattan samples, as indicated in chemical composition analysis (Table 4). As expected, at RHs above 75\%, C. zollingeri with a $20 \mathrm{~mm}$ diameter demonstrated lower moisture sorption in comparison with $C$. zollingeri with a $30 \mathrm{~mm}$ diameter and C. ornatus in the top and bottom parts during both adsorption and desorption runs. The effect of high lignin content in rattan with a $30 \mathrm{~mm}$ diameter on moisture sorption might be offset by higher extractive and ash contents in C. zollingeri with a $20 \mathrm{~mm}$ diameter. The moisture sorption results are in accordance with the volumetric swelling values and confirmed a better hydrophobicity of C. zollingeri with a $20 \mathrm{~mm}$ diameter as compared with the other rattan samples.

The EMC values vary a lot in rattan age and the length of cane [2]. The results from dynamic moisture sorption analysis imply that the cane type and diameter should be considered when using rattan products for applications in high humidity conditions. The rattan-water vapor interaction study also helps to understand the material properties of rattan canes before harvesting. For instance, a young rattan could have similar or higher strength properties than a mature one because the plant produces an over-built stem that could withstand future load requirements [41]. In all aspects of properties, consideration of diameter class before harvesting is very important because it can lead to the shortening of the plantation and harvesting processes.

\subsection{Mold and Decay Tests}

After 10 days of incubation, mold growth was visually evaluated and graded on rattan samples of different diameter classes (Figure 4). The highest average mold rating was found on C. ornatus and the bottom sample of the $30 \mathrm{~mm} \mathrm{C}$. zollingeri. For C. zollingeri, statistically significant differences were neither observed between the bottom and top of the canes nor between the $30 \mathrm{~mm}$ and $20 \mathrm{~mm}$ diameter classes. Rattan hemicelluloses are partly composed of water-soluble polysaccharides, such as arabinogalactan, and partly of galactoglucomannan [18]. The sugar and acid units of hemicelluloses, such as arabinopyranose, arabinofuranose, galactose, methylglucuronic acid, and galacturonic acid are types of sugars and acids that are a source of fungal food. The chemical composition of the rattan samples illustrated a considerably lower lignin content in C. ornatus. This could be the reason for the higher mold infestation of this rattan type. However, differences in mold infestation between the bottom and top samples did not differ significantly.

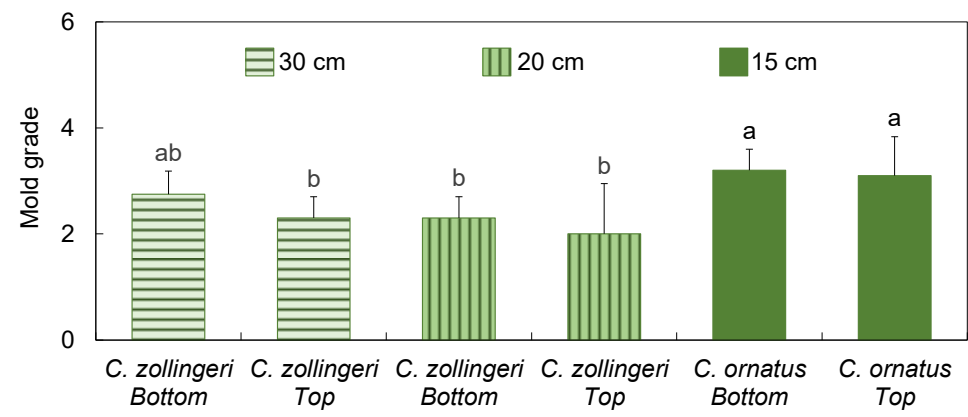

Figure 4. Mold grading of rattan samples for different diameter classes. Error bars show standard deviations. Bars with different letters indicate that there is a significant difference $(p \leq 0.05)$, as determined by ANOVA and Duncan's multiple range test.

The decay resistance of rattan samples against the white-rot fungus Trametes versicolor is shown in Figure 5. To validate the results, beech and pine sapwood samples were selected as controls. Among all rattan samples of different diameter classes, the C. ornatus illustrated the highest mass loss. These results are in accordance with the ones from mold test and dynamic vapor sorption analysis. The differences of mass loss between the top and bottom 
samples of each diameter class were statistically insignificant. Among the three diameter classes, C. zollingeri of $20 \mathrm{~mm}$ diameter showed the lowest mass loss for both the bottom and top samples (Figure 5). However, no obvious trend was observed for mass loss of both the top and bottom samples in all diameter classes.

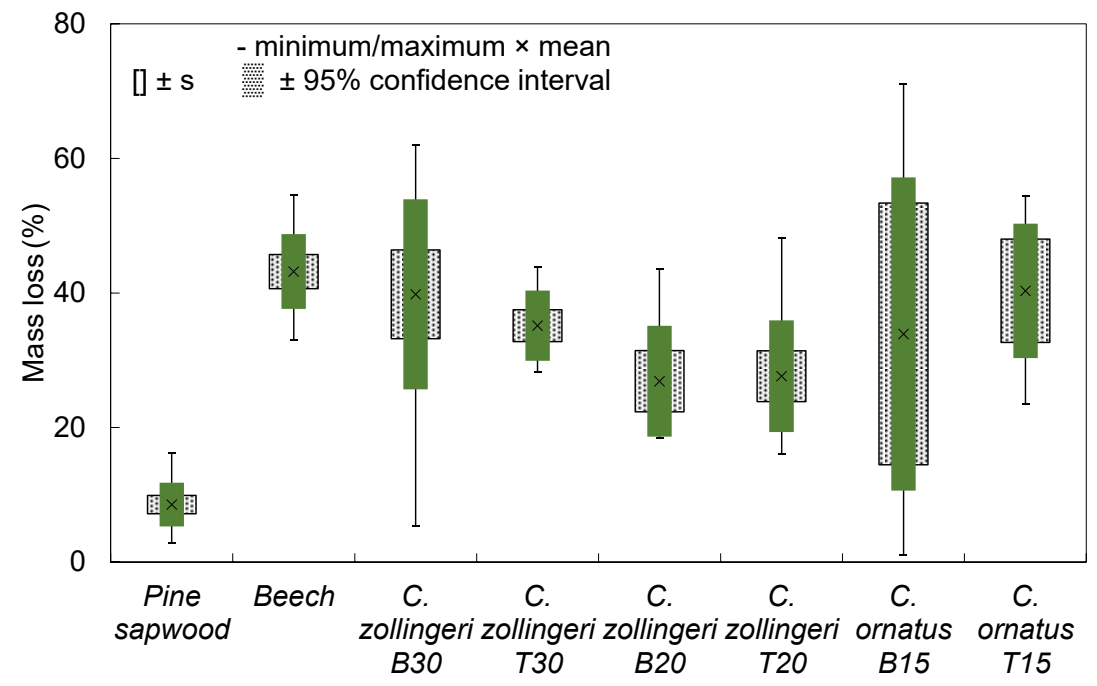

Figure 5. Mass loss of bottom/mature (B) and top/juvenile (T) rattan samples of different diameter classes $(30,20$, and $15 \mathrm{~mm})$ after decay test with the white-rot fungus Trametes versicolor.

As white-rot decay has a common feature of degrading lignin, cellulose, and hemicelluloses, the resistance of lignocellulosic material to this fungus highly depends on the relative proportion of their compositional polymers, i.e., it depends on the lignin content, carbohydrate ratio, and lignin monomer composition (mainly guiaicyl lignin) [42-44]. High mass loss of $C$. ornatus samples compared with the other rattan samples could be related to their considerably low lignin content, as demonstrated in chemical composition analysis (Table 4).

\section{Conclusions}

This study showed that C. zollingeri with a $20 \mathrm{~mm}$ diameter had the highest basic density in both bottom and top samples compared to $C$. zollingeri with a $30 \mathrm{~mm}$ diameter and C. ornatus with a $15 \mathrm{~mm}$ diameter. The reasoning for such higher density was supported by the anatomical features of higher vascular bundle frequency and longer thick-walled fibers. In addition, C. zollingeri with a $20 \mathrm{~mm}$ diameter exhibited the lowest volumetric swelling from an oven-dry condition to complete saturation. When water vapor sorption analysis was performed, this diameter class showed the lowest EMC at 95\% RH, which verified its better dimensional stability even at high humidity levels. In addition, better resistance against mold and mass loss from white-rot fungal decay were also observed. Those properties followed a statistically similar pattern with sample height (bottom and top). From these findings, we conclude that $C$. zollingeri with a $20 \mathrm{~mm}$ diameter class exhibited better stability, moisture properties, and durability from older rattan with a 30 $\mathrm{mm}$ diameter class. On the contrary, C. ornatus with a $15 \mathrm{~mm}$ diameter showed inferior properties. Further research work needs to be extended to the evaluation of different mechanical properties.

Author Contributions: Conceptualization, S.A.A. and S.A.; methodology, S.A.A., R.H. and S.A.; software, S.A.A.; validation, S.A.A., R.H. and S.A.; formal analysis, S.A.A.; investigation, S.A.A.; R.H. and C.B.; visualization, S.A.A.; R.H. and C.B.; data curation, S.A.A. and S.A.; writing-original draft preparation, S.A.A; writing-review and editing, all authors. All authors have read and agreed to the published version of the manuscript.

Funding: The authors acknowledge funding provided by IKEA of Sweden. 


\section{Institutional Review Board Statement: Not applicable.}

Informed Consent Statement: Not applicable.

Data Availability Statement: Not applicable.

Conflicts of Interest: The authors declare no conflict of interest.

\section{References}

1. Szczepanowska, H.M. Deconstructing rattan: Morphology of biogenic silica in rattan and its impact on preservation of Southeast Asian art and artifacts made of rattan. Stud. Conserv. 2018, 63, 356-374. [CrossRef]

2. $\quad$ Bhat, K.M.; Thulasidas, P.K.; Mohamed, C.P. Strength properties of ten south Indian canes. J. Trop. For. Sci. 1992, 5, 26-34.

3. Sastry, C.B. Rattan in the twenty-first century- an overview of major issues and needs for the global development of rattan. Unasylva 2001, 205, 3-12.

4. Olorunnisola, A.O.; Adefisan, O.O. Trial production and testing of cement-bonded particleboard from rattan furniture waste. Wood Fiber Sci. 2002, 34, 116-124.

5. Sharma, M.; Sharma, C.L.; Haokip, D. Anatomical and physical characteristics of some rattan species. J. Indian Acad. Wood Sci. 2018, 15, 132-139. [CrossRef]

6. Siebert, S.F. The Nature and Culture of Rattan: Reflection of Vanishing Life in The Forests of Southeast Asia; University of Hawai'i Press: Honolulu, HI, USA, 2012.

7. Krisdianto, K.; Jasni, J.; Tutiana, T. Anatomical properties of nine indigenous rattan species of Jambi, Indonesia. Indonesian J. For. Res. 2018, 5, 147-161. [CrossRef]

8. Ariffin, W.T.W.; Hisain, S.; Salleh, A.H. Transfer of Technology Model: Rattan Furniture Making Unit; International Network for Banboo and Rattan (INBAR), Forest Research Institute Malaysia: Kuala Lumpur, Malaysia, 2001.

9. Bhat, K.M.; Varghese, M. Anatomical basis for density and shrinkage behavior of rattan stem. J. Inst. Wood Sci. 1991, 12, 123-130.

10. Tomlinson, P.B.; Fisher, J.B.; Spangler, R.E.; Richer, R.A. Stem vascular architecture in the rattan palm Calamus (ArecaceaeCalamoideae-Calaminae). Am. J. Bot. 2001, 88, 797-809. [CrossRef] [PubMed]

11. Yang, S.; Xiang, E.; Shang, L.; Liu, X.; Tian, G.; Ma, J. Comparison of physical and mechanical properties of four rattan species grown in China. J. Wood Sci. 2020, 66, 3. [CrossRef]

12. Shang, L.; Jiang, Z.; Liu, X.; Tian, G.; Ma, J.; Yang, S. Effect of modification with methyl methacrylate on the mechanical properties of Plectocomia kerrana rattan. BioResources 2016, 11, 2071-2082. [CrossRef]

13. Abasolo, P.W.; Yoshida, M.; Yamamoto, H.; Okuyama, T. Microfibril angle determination of rattan fibers and its influence on the properties of the cane. Holzforschung 2000, 54, 437-442. [CrossRef]

14. Luo, Z.; Zhang, X.; Lu, B.; Pan, B.; Ruan, Z. Mechanical properties and test methods of rattan. Furnit. Des. Room Dec. 2012, 7, 108-110.

15. Abasolo, P.W.; Yamamoto, H.; Yoshida, M.; Mitsui, K.; Okuyama, T. Influence of heat and loading time on the mechanical properties of Calamus merrillii Becc. Holzforschung 2002, 56, 639-647. [CrossRef]

16. Bhat, K.M.; Nasser, K.M.M.; Thulasidas, P.K. Anatomy and identification of south Indian rattans (Calamus species). IAWA J. 1993, 14, 63-76. [CrossRef]

17. Abasolo, W.P. Properties of rattan cane as basis for determining optimum cutting cycle of cultivated Calamus merrillii. J. Trop. For. Sci. 2015, 27, 176-188.

18. Sanusi, D. Rotan: Kekayaan Belantara Indonesia; Brilian Internasional: Surabaya, Indonesia, 2012. (In Indonesian)

19. Hamid, N.H.; Hale, M. Decay threshold of acetylated rattan against white and brown rot fungi. Int. Wood Prod. J. 2012, 3, 96-106. [CrossRef]

20. Tiryaki, S.; Bardak, S.; Aydin, A.; Nemli, G. Analysis of volumetric swelling and shrinkage of heat treated woods: Experimental and artificial neural network modeling approach. Maderas Ciencia. Tecnol. 2016, 18, 477-492. [CrossRef]

21. Ghavidel, A.; Hosseinpourpia, R.; Gelbrich, J.; Bak, M.; Sandu, I. Microstructural and chemical characteristics of archaeological white elm (Ulmus laevis P.) and poplar (Populus spp.). Forests 2021, 11, 10271. [CrossRef]

22. EN 15403; Solid Recovered Fuels-Determination of Ash Content. European Committee for Standardization: Brussels, Belgium, 2011.

23. Hosseinpourpia, R.; Adamopoulos, S.; Walther, T.; Naydenov, V. Hydrophobic formulations based on tall oil distillation products for high-density fiberboards. Materials 2020, 13, 4025. [CrossRef]

24. Ahmed, S.A.; Sehlstedt-Persson, M.; Morén, T. Development of a new rapid method for mould testing in a climate chamberPreliminary tests. Eur. J. Wood Prod. 2013, 71, 451-461. [CrossRef]

25. Sehlstedt-Persson, M.; Karlsson, O.; Wamming, T.; Morén, T. Mold growth on sapwood boards exposed outdoors: The impact of wood drying. For. Prod. J. 2011, 61, 170-179. [CrossRef]

26. EN 113-2; Durability of Wood and Wood-Based Products-Test Method against Wood Destroying Basidiomycetes-Part 2: Assessment of Inherent or Enhanced Durability. European Committee for Standardization: Brussels, Belgium, 2020.

27. Bravery, A.F. A miniaturised wood-block test for the rapid evaluation of wood preservative fungicides. In Proceedings of the 10th Annual Meeting, Peebles, Scotland, 17-22 September 1978. 
28. Weiner, G.; Liese, W. Rattans- stem anatomy and taxonomic implications. IAWA J. 1990, 11, 61-70. [CrossRef]

29. Liu, X.; Tian, G.; Shang, L.; Yang, S.; Jiang, Z. Compression properties of vascular bundles and parenchyma of rattan (Plectocomia assamica Griff). Holzforschung 2014, 68, 927-932. [CrossRef]

30. Sulaiman, A.; Lim, S.C. Anatomical and physical features of 11-y-old cultivated Calamus manan in peninsular Malaysia. J. Trop. For. Sci. 1991, 3, 372-379.

31. Gu, Y.; Zhang, J. Tensile properties of natural and synthetic rattan strips used as furniture woven materials. Forests 2020, 11, 1299. [CrossRef]

32. Bhat, K.M.; Liese, W.; Schmitt, U. Structural variability of vascular bundles and cell wall in rattan stem. Wood Sci. Technol. 1990, 24, 211-224. [CrossRef]

33. Wahab, R.; Sulaiman, O.; Samsi, H.W. Basic density and strength properties of cultivated Calamus manan. J. Bamboo Rattan 2004, 3, 35-43. [CrossRef]

34. Ali, A.R.M.; Mohmod, A.L.; Khoo, K.C.; Kasim, J. Physical properties, fiber dimensions and proximate chemical analysis of Malaysian rattan. Thai J. For. 1995, 14, 59-70.

35. Chowdhury, M.Q. Assessment of some physical and mechanical properties of golla bet (Daemonorops jenkinsiana) from northeastern region of Bangladesh. J. Bamboo Rattan 2004, 3, 195-201. [CrossRef]

36. Yang, L.; Tian, G.; Yang, S.; Shang, L.; Liu, X.; Jiang, Z. Determination of fiber saturation point of rattan (Calamus simplicifolius) using the LF-NMR and two conventional methods. Wood Sci. Technol. 2020, 54, 667-682. [CrossRef]

37. Tellu, A.T. Chemical properties of different rattan species traded in Central Sulawesi Province. Biodiversitas 2008, 9, 108-111. (In Indonesian) [CrossRef]

38. Hillis, W.E. High temperature and chemical effects on wood stability. Part 1: General considerations. Wood Sci. Technol. 1984, 18, 281-293. [CrossRef]

39. Salmén, L. Viscoelastic properties of in situ lignin under water-saturated conditions. J. Mater. Sci. 1984, 19, 3090-3096. [CrossRef]

40. Hosseinpourpia, R.; Adamopoulos, S.; Mai, C. Dynamic vapour sorption of wood and holocellulose modified with thermosetting resins, Wood Sci. Technol. 2016, 50, 165-178.

41. Tomlinson, P.B. The Structural Biology of Palms; Clarendon Press: Oxford, UK, 1990.

42. Chen, M.; Wand, C.; Fei, B.; Ma, X.; Zhang, B.; Zhang, S.; Huang, A. Biological degradation of Chinese fir with Trametes versicolor (L.) Lloyd. Materials 2017, 10, 834. [CrossRef]

43. Kamperidou, V. The biological durability of thermally- and chemically-modified black pine and poplar wood against basidiomycetes and mold action. Forests 2019, 10, 1111. [CrossRef]

44. Bari, E.; Daniel, G.; Yilgor, N.; Kim, J.S.; Tajick-Ghanbary, M.A.; Singh, A.P.; Ribera, J. Comparison of the decay behavior of two white-rot fungi in relation to wood type and exposure conditions. Microorganisms 2020, 8, 1931. [CrossRef] 